\title{
A new Ingolfiellid (Crustacea,Amphipoda, Ingolfiellidae) from an anchialine pool on Abd al Kuri Island, Socotra Archipelago, Yemen
}

\author{
Valentina Iannilli ${ }^{1,2, \dagger}$, Ronald Vonk $k^{3,4, \neq}$ \\ I ENEA, Technical Unit of Sustainable Management of Agro-Ecosystems, C.R. Casaccia via Anguillarese \\ 301, 00123 Rome, Italy 2 Museo Civico di Storia Naturale di Verona, Lungadige Porta Vittoria, 9, I-37129 \\ - Verona, Italy 3 Naturalis Biodiversity Center, Darwinweg 2, P.O. Box 9517, 2300 RA Leiden, The Ne- \\ therlands 4 Institute for Biodiversity and Ecosystem Dynamics, University of Amsterdam, Amsterdam 1098 \\ $X H$, The Netherlands \\ † urn:lsid:zoobank.org:author:73E6D417-5CD1-4749-989E-BF336E24AE16 \\ † urn:lsid:zoobank.org:author:A12CE9EA-80D0-4AF2-83D1-70A87EC56A93 \\ Corresponding author: Ronald Vonk (ronald.vonk@naturalis.nl)
}

Academic editor: C. O. Coleman | Received 15 April 2013 | Accepted 15 May 2013 | Published 20 May 2013

urn:lsid:zoobank.org:pub:6F033BB9-B120-412A-957B-OEA64874CD47

Citation: Iannilli V, Vonk R (2013) A new Ingolfiellid (Crustacea, Amphipoda, Ingolfiellidae) from an anchialine pool on Abd al Kuri Island, Socotra Archipelago, Yemen. ZooKeys 302: 1-12. doi: 10.3897/zookeys.302.5261

\begin{abstract}
Ingolfiella arganoi sp. n. from Abd al Kuri Island in the Arabian Sea is described from two specimens, a male and a female. The western shore of the Indian Ocean was hitherto a vacant spot in the distribution of circumtropical shallow marine interstitial ingolfiellids and therefore the location of the new species fills a meaningful gap in the geography of the family. Morphologically, the new species shows close affinities with I. xarifae from the Maldives.
\end{abstract}

\section{Keywords}

Taxonomy, meiofauna, subterranean thalassoid amphipods, beach environment, mesopsammon, Arabian Sea 


\section{Introduction}

During sampling of aquatic fauna from the Socotra Archipelago conducted by Roberto Argano and co-workers (Taiti and Ferrara 2004), two specimens of a new species of Ingolfiella were found in the mesopsammon of an anchialine pool on Abd al Kuri Island (Fig. 1a, b). Anchialine water bodies are well known to offer a great potential of unique species (Becking et al. 2011 and references herein). Ingolfiellid amphipods are sporadically found and are confined to fresh, brackish, and marine ground- and cave waters, and even ocean floor habitats (Ruffo 1950; Spooner 1959, 1960; Vonk and Schram 2003). They are seldom observed in great numbers and the specimens from the small island of Abd al Kuri are no exception to this rule; only two specimens were found. Their discovery points to a long-awaited geographic link in the chain of locality records in this group, as they bridge a gap in the so often presumed Tethys distribution. Until now, no ingolfiellid has been reported between the coasts of Greece in the west and the beaches of the Maldives in the east - a stretch well over $6000 \mathrm{~km}$.

The late Sandro Ruffo, curator of the natural history museum of Verona, started the work on the two specimens from Abd al Kuri, helped by one of us (V.I.), but did not finish it because he was not confident about the status of a new species based on so little material and the presence of only few available distinctive morphological characters. A few years later we decided to take up this work and bring it to fruition because it provides relevant new information on the geographic range of ingolfiellids and on new combinations of character states as shown by these specimens from an anchialine environment in the Arabian Sea.

\section{Material and methods}

The two specimens were collected on a beach on the north coast of Abd al Kuri Island, Republic of Yemen, $\left(12^{\circ} 11.988^{\prime} \mathrm{N}, 52^{\circ} 15.943^{\prime} \mathrm{E}\right)$, close to a little village called Bait

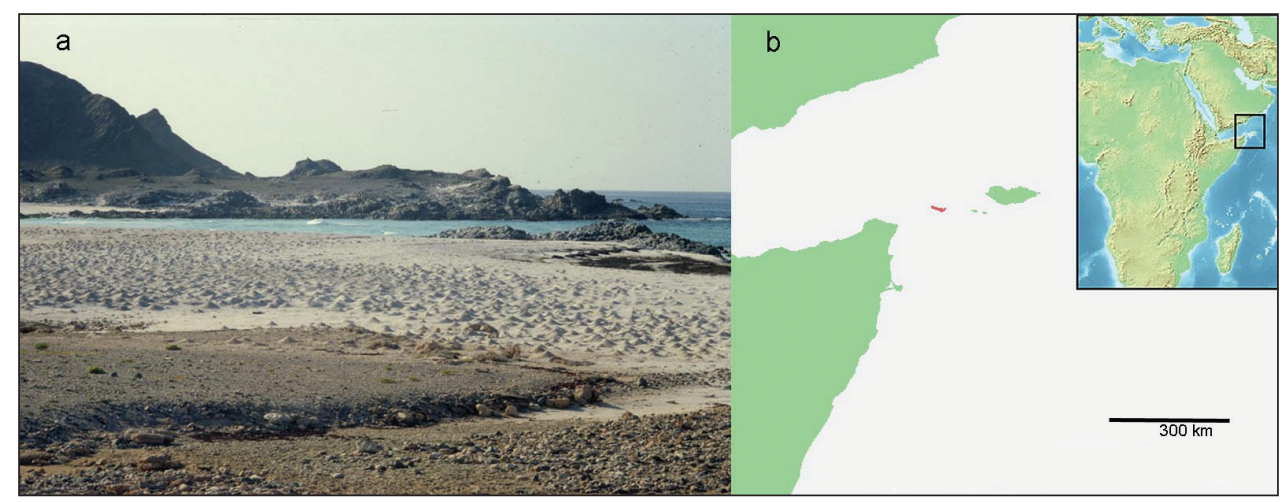

Figure I. a Abd al Kuri, beach, with gully in foreground, scoured in the sand by rainwater during the wet season (photograph taken while standing at the collection site by R. Argano). Pointed hills on the white beach sand are Ocypode crab burrows b position of Abd al Kuri Island (red color) in the Arabian Sea. 
Eesa. Sampling was done with a micro-creel in coarse sand at the bottom of a pool in an otherwise dry wadi, running as a slight depression to the sea (pers. comm. R. Argano). The approximate position of the pool with unknown salinity from which the ingolfiellids were collected on 7 February 2000 is shown in Fig. 1a .

\section{Taxonomy}

Order AMPHIPODA Latreille, 1802

Suborder INGOLFIELLIDEA Hansen, 1903

Family Ingofiellidae Hansen, 1903

Genus Ingolfiella Hansen, 1903

\section{Ingolfiella arganoi sp. $\mathrm{n}$.}

urn:Isid:zoobank.org:act:807BB2C1-62F5-4930-A55B-74AF21C033EB

http://species-id.net/wiki/Ingolfiella_arganoi

Figs 2-5

Material examined. Two specimens: one male holotype, $1.4 \mathrm{~mm}$, dissected and mounted in Faure's liquid on slide MSNVRCr nr. 434; one preparatory female paratype on two slides MSNVRCr nr. 470 in Museo di Storia Naturale di Verona, Italy.

Diagnosis. Lateral lobes on frontal margin of head developed. Maxillule, basal endite ( = outer lobe) left and right with asymmetrical seta. Gnathopods 1 and 2 carpochelate with oblique palm, dactyli with a serrated inner margin with four teeth. Female with extra palmar margin robust seta. Oöstegites on pereiopod 3 and 4, with three regularly placed small button-like processes. Gills present on P3-5. Dactylus of P3 and P4 with slender trifid unguis; P5-7 with thicker bifid unguis, not clearly separated from dactylus. Pleopods 1-3 subtrapezoidal and similar, except first pleopod in male which is flexed and has a broadened tip. Uropod 1 with inner ramus about 1.5 times as long as outer ramus; uropod 2 peduncle without basofacial spine and with two diagonal rows of sturdy rectangular setae, three rows in female, individual setae mostly bifid but with some of them trifid at the tip.

Etymology. The new species is named after Roberto Argano (University of Rome "la Sapienza") who collected the specimens and gave them to the Verona Museum for study.

Description. Body elongate, without coloration, all segments laterally compressed. Head (Fig. 2a) with lateral margin rounded; lateral or 'ocular lobes' present on frontal margin, well developed, suboval. Pleonites I-III with diffusely developed posteriorly rounded epimeral plates adorned with simple seta, a superficial marginal edge slightly visible. Urosomite III subcilindrical, slightly longer than deep, enclosing base of telson and uropod III.

Antennule (Fig. 2a), peduncular article slightly shorter than head; article ratio 1:0,42:0,42; flagellum of 4 articles, half the length, articles 2-4 with 1 aesthetasc; accessory flagellum slightly shorter than flagellar articles $1+2$, three articles. 


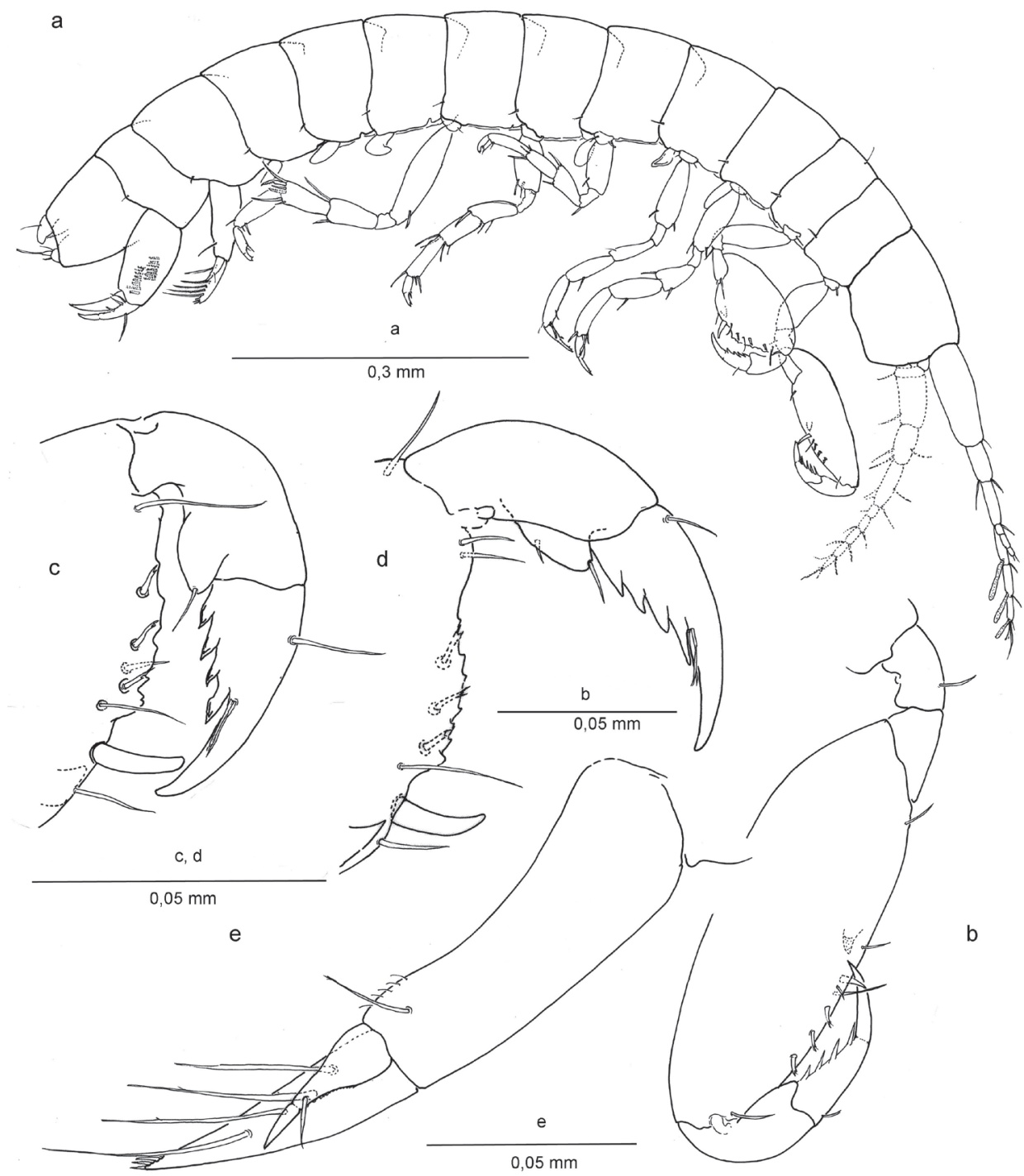

Figure 2. Ingolfiella arganoi sp. n., male holotype $1.4 \mathrm{~mm}$. a habitus, male $1.4 \mathrm{~mm} \mathbf{b}$ left gnathopod I, lateral c right gnathopod II, lateral d left gnathopod II, medial e right uropod I, lateral.

Antenna (Fig. 2a) subequal in length to antennule; flagellum of 5 articles, slightly shorter than half the length of peduncle, the last article bearing one aesthetasc (antenna drawn by S. Ruffo but not present in mounted slides).

Mandibles with non-triturative molar process, spiniform. Left mandible (Fig. 5d) with broad incisor, right mandible (Fig. 5c) with fine serrations on lacinia and molar process margin.

Maxillule (Figs 5a, e) coxal endite (= inner lobe) with 3 simple setae; basal endite ( = outer lobe) with six robust setae of which the second one on the medial side has 
four teeth in the left maxillule and three teeth in the right one. Endopod ( = palp) twosegmented, distal segment with two setae.

Maxilla (Fig. 5b) with short, equally long plates, each bearing four distal setae.

Maxilliped (Fig. 5f) basal endite slender, with one simple seta; ischium with two setae; merus and carpus without setae; propodus with one seta; dactylus with one lateral robust seta and distally two long setae, unguis not discernible.

Oöstegites on pereiopods III-IV (Figs 3d, e), suboval, without setae and with 3 button-like processes.

Coxal gills on pereiopods III-V.

Gnathopod I (Figs 2b, 3b) carpo-subchelate, palm strongly oblique, carpus 2.4 times as long as wide, palm margin smooth, not serrated, and with three short, bifid flagellate setae along lateral side of margin, and one simple seta on palm angle in male. In female two of such setae of which one placed closer to the row of three bifid setae. Just posterior to the palmar angle seta is a broad triangular spine on the medial side in the male, and three spines in the female: two smaller ones and a larger, more pointed one. Dactylus with four long spines along posterior margin and thin setules or grooves at the base of the unguis.

Gnathopod II (Figs 2c,d; 3c) Carpo-subchelate, palm oblique, carpus stronger than in gnathopod I, subtrapezoidal, carpal index $=4.6$, palm angle defined by one large seta and one smaller spine in female (Fig. 3c), one seta in male (Figs 2c,d), and with triangular tooth proximal to the palmar angle seta, palm margin with irregular serrations; propodus strong with lobe on lateral side ending in a setule, less pronounced in female; dactylus with four strong teeth enforced with thick margins on lateral side and a groove or bundled setules at the base of the unguis.

Pereipods III - IV (Figs 3d,e) with two distal setae on dactylus at the base of the unguis, and three distal setae on propodus, one of them long and apically bifid, unguis apically trifid. Oöstegites with in both pereiopods regularly placed series of 3 buttonlike processes.

Pereiopods V-VII (Figs 4a,b,c) progressively longer towards P7; basis of P5 broad, that of P7 slender; carpus of P5 with two long and stout distal setae, others shorter; carpus of $\mathrm{P} 7$ with broad, curved and modified comb setae; merus of P7 with long distal seta; dactyli with two small setae distally; unguis bifid.

Pleopods I-III (Fig. 2a) subtrapezoidal, without setae. Pleopod I in male deformed or broadened distally.

Uropod I (Figs 2e, 4e) male: protopod with one seta and a row of fine setules on anterolateral margin; exopod with very feeble segment suture and one seta placed at two-thirds the length; endopod with terminal row of spines and four long setae laterally. In female protopod with three setae; endopod with six long setae laterally.

Uropod II (Figs 3a, 4d), protopod with two oblique comb rows in male, and three in female; setae of rows more or less rectangular with bifid or trifid, or even comb-like tips; endopod slightly longer than exopod, sharper, and with four setae.

Uropod III (Fig. 2a) short, 2 segmented, with one ramus, protopod with 2 distal setae, ramus short with 1 distal seta. 


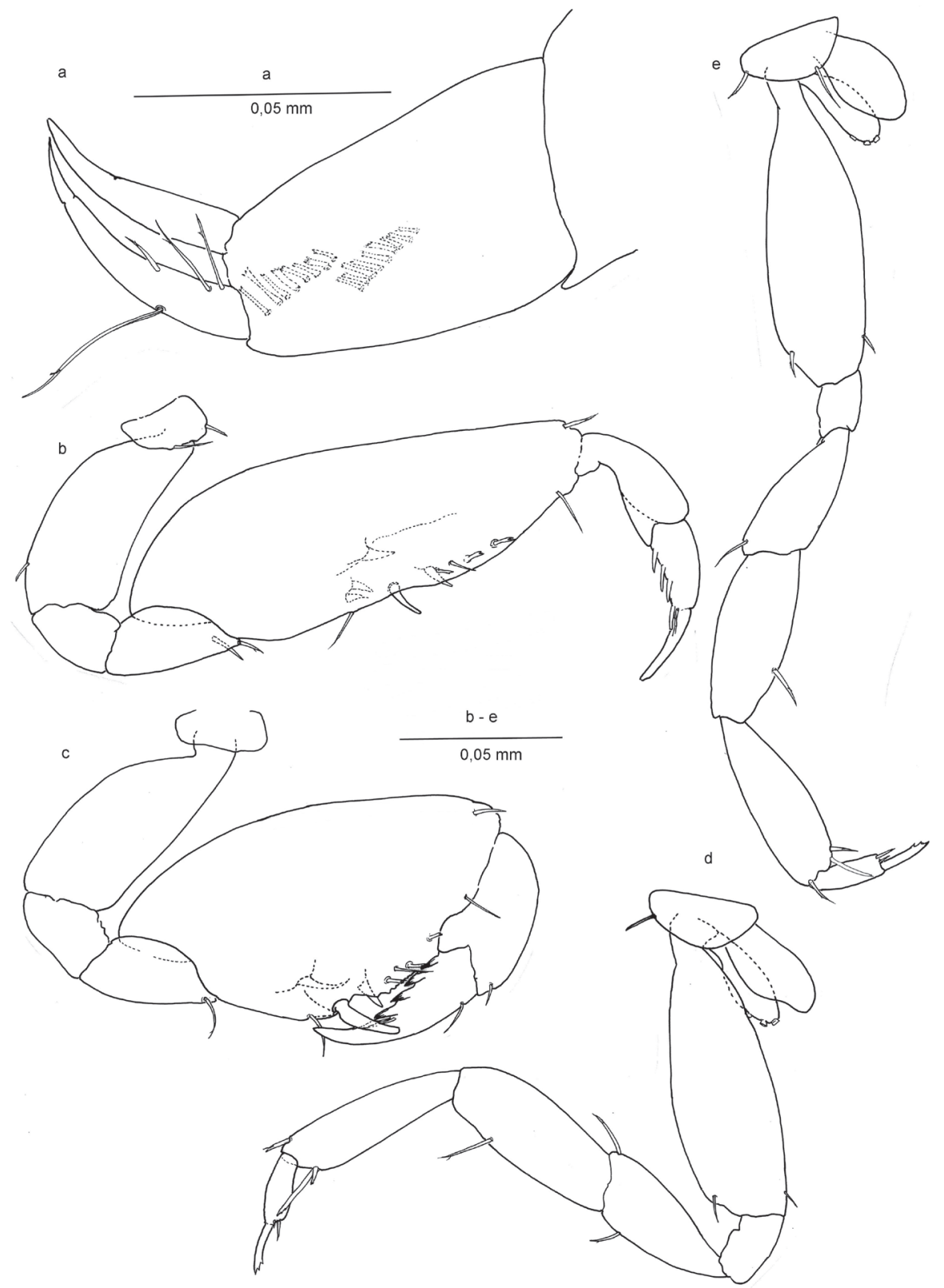

Figure 3. Ingolfiella arganoi sp. n., male holotype $1.4 \mathrm{~mm}$. a right uropod II, lateral; female paratype $1.5 \mathrm{~mm}$. b right gnathopod I, lateral $\mathbf{c}$ right gnathopod II, lateral $\mathbf{d}$ right pereiopod III, lateral e right pereiopod IV, lateral.

Telson (Fig. 2a) globose, with 1 pair of long dorsal setae.

Differences between male and female: gnathopods without extra palmar seta in male, and uropod II without a third comb row in male. Pleopod I in the male has a broadened tip. 
a

C

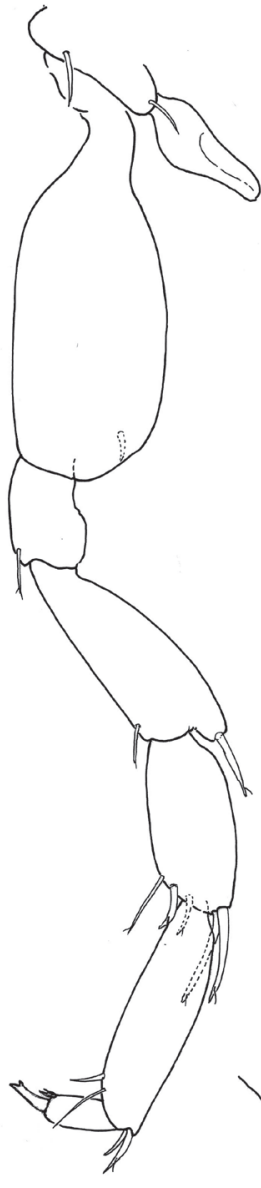

e

b

b<smiles>C1CCC1</smiles>

$+$

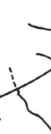<smiles>C1CC2(C1)CCC2</smiles><smiles>C1CCCC1</smiles><smiles>CCC</smiles>
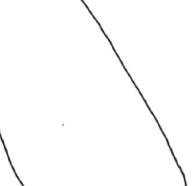

Y
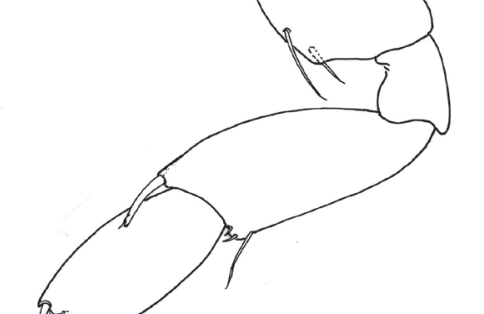

c

c 
a

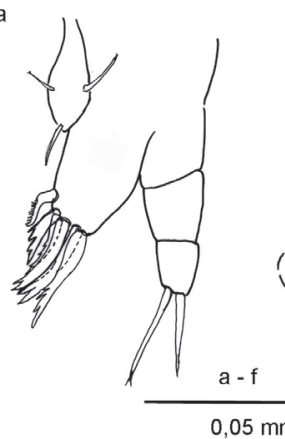

b
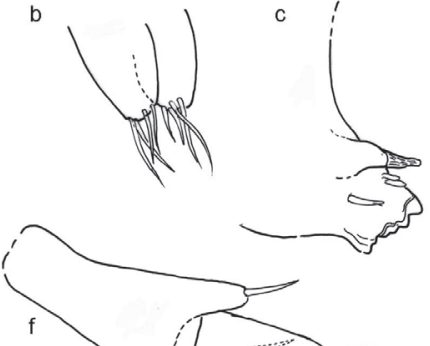
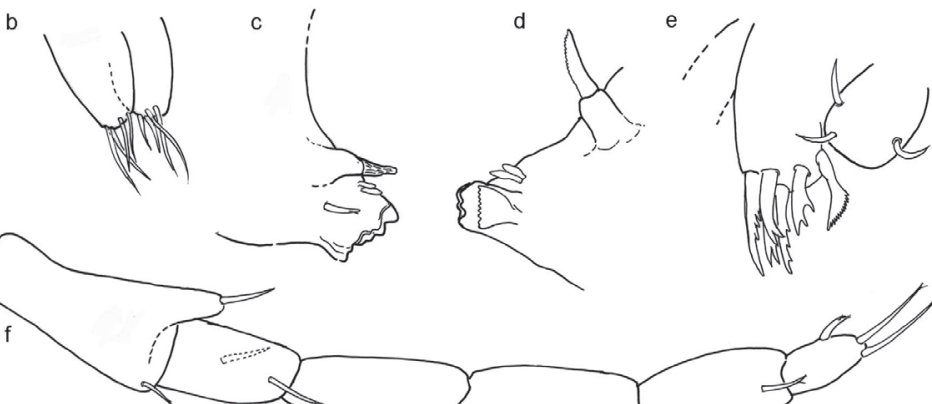

Figure 5. Ingolfiella arganoi $\mathrm{sp}$. n., female paratype. a left maxillule $\mathbf{b}$ maxilla $\mathbf{c}$ right mandible $\mathbf{d}$ left mandible e right maxillule $\mathbf{f}$ right maxilliped.

For now, five clear morphological differences justify the designation of a new species that also is geographically quite far away from its nearest congeners. These differences can be observed in the four spines on the medial margin of the propodus of gnathopod I - three spines in I. xarifae; subtrapezoidal carpus of gnathopod 2 - elongate oval in xarifae; palmar index of gnathopod 2 is 4.6 - against 6.4 in xarifae; palm of gnathopod 2 strongly serrate - almost smooth in xarifae; pereiopod VII with specialized, combed, robust setae distally on carpus - not present in xarifae.

The differences in the placement, form and number of setae have shown to be quite consistent in the case of the poorly setose ingolfiellids (Vonk and Sanchez 1991). The spines and setae that have remained, are perhaps critically functional due to selective reductive factors in the underground environment.

The oöstegites have 3 small button-like processes. The same character was described in Ingolfiella alba Iannilli et al., 2008, where also three small button-like processes are present, but here from P3 to P5. Re-examination of I. xarifae typus by Sandro Ruffo and V.I. allowed them to observe also on the oöstegites of this species the button-like processes, as described for I. alba. Something similar was described in Metaingolfiella mirabilis Ruffo, 1969, although the processes were smaller and more numerous. These structures are probably present in other Ingolfiella species but have yet to be observed and described (Iannilli et al., 2008). Stock (1979) observed in I. quadridentata Stock, 1979, that oöstegites found on P3 and P4 were: "curved, truncate at tip, provided with 3 apical teeth, but without setae."

In other amphipods with preparatory females (females in a moult stage in between two brooding periods), these structures are sometimes present on the oöstegites (pers. comm. D. Jaume). Slattery (1985) mentions the development of oöstegites in infaunal amphipod families of Phoxocephalidae and Haustoriidae undergoing three stages of development: buds (of the oostegite itself), preparatory (moderately long oöstegites with some setae), and mature (long oöstegites, curved, and setose to form a brood-carrying pouch or marsupium). If the buttons, that occur in threesomes on the oöstegites of pereiopods III and IV in I. arganoi, can be observed in other ingolfiellids as being present at the same time with setae this might prove their precursory role. On the other 
hand, in contradiction to these observations, are our studies of abundant material of I. alba, that shows this character. The material consists of several individuals collected in different years (from 1992 to 2004) and in different months of the year. We could verify that the structure is always the same, namely the presence of only three buttonlike processes, and we did not find setae on the oöstegites. So an interpretation of these structures being preparatory setae seems not convincing for Ingolfiella species.

In agreement with Ruffo and Vigna Taglianti 1989 the new species could be placed in the subgenus Tethydiella, although Vonk and Schram (2003), basing their phylogeny on more characters, did not use the splitting of Ingolfiella into genus and subgenera as several taxa are poorly described when compared to recent taxonomic descriptions and only few species have both sexes well known.

However, the species-groups in sensu Ruffo (1970) and Ruffo and Vigna Taglianti (1989) may still be of practical taxonomic use and the geographical location as well as the morphological diagnosis fits the Tethydiella group. Of course, more detailed biogeographic data are required to reconstruct the history of the actual distribution of Ingolfiellidae (Iannilli et al. 2008).

\section{Subterranean thalassoid crustaceans of the region}

The present discovery represents the westernmost record of ingolfiellids in the Indo-Pacific Oceans. The Red Sea shores, Gulf of Aden, and the shores of the Arabian sea are relatively unknown areas for stygobiont and marine interstitial crustaceans. Geographically it is an interesting region as it forms the corridor between the better known Mediterranean and south east Asian/Australian stygofaunas. Sampling by Stock and Nijssen (1965) on Entedebir Island in the southern Red Sea revealed the presence of the circumtropical marine groundwater amphipod genus Psammogammarus (Vonk and Stock 1987; Vonk 1990; Van der Ham and Vonk 2003; Tomikawa et al. 2010; Vonk et al. 2011), suggesting the possible occurrence of the usual inhabitants of the present coastal groundwater biotope. In this respect also Angeliera xarifae Siewing, 1959 can be mentioned. This is a microparasellid isopod, sampled from coastal groundwater of Abd al Kuri during the Xarifa expedition of 1957 ( Wallace and Zahir 2007). In 2005 Iannilli et al. described the bogidiellid amphipod Nubigidiella theresiae, from a freshwater well at Bin Aissa, on Abd al Kuri Island. Until 2005 the only amphipod species known from the subterranean waters of Socotra was Indoweckelia superstes Holsinger \& Ruffo, 2002, from a water well on the main island of Socotra. These are mainly freshwater subterranean amphipods with well investigated marine affinities. Recently the coastal aquifer waters of Oman showed to contain Metacrangonyx (Jaume \& Vonk, 2012), a stygobiont amphipod with proven marine origins (Bauzà-Ribot et al. 2012), distributed in marine and freshwaters from the Caribbean to its current eastern border, the Indian Ocean. On Socotra and Abd al Kuri new cyclopoid copepods were described from brackish wells and caves (Mirabdullaev et al. 2002) showing the island's isolated status. The first inland, freshwater ingolfiellid of the region, as well as those from deep marine sediments, are still to be discovered. 


\section{Acknowledgements}

We thank Leonardo Latella and Roberta Salmaso (Museo Civico di Storia Naturale, Verona) for help and access to the crustacean collection; Traudl Krapp (Zoologisches Forschungsmuseum Alexander Koenig, Bonn) for her indispensable work on amphipod identifications and cataloguing in the Verona collection; Damiá Jaume (Institut Mediterrani d'Estudis Avanzats, Mallorca) for his comments on peracarid development and taxonomy; Bert Hoeksema (Naturalis Biodiversity Center, Leiden) for close reading; Kees van den Berg (Naturalis Biodiversity Center, Leiden) for new microscopy tools and assistance; and Roberto Argano (University La Sapienza, Rome) for donating his expedition specimens. We dedicate this study, in the warmest remembrance, to the late Sandro Ruffo. The work at the Verona museum by RV was supported by Naturalis bench fee grants of 2011 and 2012.

\section{References}

Bauzà-Ribot MM, Juan C, Nardi F, Oromí P, Pons J, Jaume D (2012) Mitogenomic phylogenetic analysis supports continental-scale vicariance in subterranean thalassoid crustaceans. Current Biology 22: 2069-2074. doi: 10.1016/j.cub.2012.09.012

Becking LE, Renema W, Santodomingo NK, Hoeksema BW, Tuti Y, De Voogd NJ (2011) Recently discovered landlocked basins in Indonesia reveal high habitat diversity in anchialine systems. Hydrobiologia 677: 89-105. doi: 10.1007/s10750-011-0742-0

Holsinger JR, Ruffo S (2002) Indoweckelia superstes $n$. gen. sp. n. from the subterranean waters of Socotra Island: the first weckeliid amphipod crustacean (Hadziidae) found in the IndoWest Pacific region. Bolletino del Museo Civico di Storia Naturale di Verona, Botanica, Zoologia 26: 27-36.

Iannilli V, Berera R, Cottarelli V (2008) Description of the first marine interstitial ingolfiellid from Philippines, Ingolfiella alba sp. n., with some remarks on the systematic of the genus (Amphipoda: Ingolfiellidae). Zootaxa 1675: 49-58.

Iannilli V, Ruffo S, Holsinger JR (2005) Nubigidiella theresiae sp. n. from Abd al Kuri Island, Yemen (Crustacea Amphipoda, Bogidiellidae), with description of a new maxillipedal structure. Bollettino del Museo Civico di Storia Naturale di Verona 29: 39-45.

Jaume D, Vonk R (2012) Discovery of Metacrangonyx in inland groundwaters of Oman (Amphipoda: Gammaridea: Metacrangonyctidae). Zootaxa 3335: 54-68.

Mirabdullaev I, Van Damme K, Dumont HJ (2002) Freshwater cyclopoids (Crustacea: Copepoda) from the Socotra Archipelago, Yemen, with description of a new species of Bryocyclops. Fauna of Arabia 19: 261-271.

Ruffo S (1950) Considerazione sulla posizione sistematica e sulla distribuzione geografica degli Ingolfiellidi. Bollettino dei Musei di Zoologia ed Anatomia Comparata della Reale Università di Torino 17: 65-73. 
Ruffo S (1966) Ingolfiella xarifae (Crustacea, Amphipoda) nuova specie dell'Oceano Indico. Memorie del Museo Civico di Storia Naturale Verona 14: 177-182.

Ruffo S (1969) Studi sui crostacei anfipodi LXIII: Descrizione di Metaingolfiella mirabilis n. gen. sp. n. (Crustacea, Amphipoda, Metaingolfiellidae fam. nova) delle acque sotterranee del Salento nell'Italia meridionale. Memorie del Museo Civico di Storia Naturale Verona 16: 239-260.

Ruffo S (1970) Considérations à propos de la systématique et de la biogéographie de Ingolfielles (Crustacea Amphipoda). Livre centenaire Emile G. Racovitza: 223-230.

Ruffo S, Vigna Taglianti A (1989) Description of a new cavernicolous Ingolfiella species from

Sardinia, with remarks on the systematics of the genus. Annali del Museo Civico di Storia Naturale Genova 87: 237-261.

Siewing R (1959) Angeliera xarifae, ein neuer Isopode aus dem Küstengrundwasser der Insel Abd-el-Kuri (Golf von Aden). Zoologischer Anzeiger 163: 365-370.

Slattery PN (1985) Life histories of infaunal amphipods from subtidal sands of Monterey Bay, California. Journal Of Crustacean Biology 5: 635-649. doi: 10.2307/1548241

Spooner GM (1959) New members of the British marine bottom fauna. Nature 183: 16951696. doi: 10.1038/1831695b0

Spooner GM (1960) The occurrence of Ingolfiella in the Eddystone shell gravel, with description of a new species. Journal of the Marine Biological Association, U.K. 39: 319-329. doi: $10.1017 /$ S0025315400013357

Stock JH (1979) New data on taxonomy and zoogeography of ingolfiellid Crustacea. Bijdr. Dierk. 49: 81-97.

Stock JH, Nijssen H (1965) Eriopisa longiramus sp. n., a new subterranean amphipod from a Red Sea Island. Bulletin of the Sea Fisheries Research Station of Israel 38: 28-39.

Taiti S, Ferrara F (2004) The terrestrial Isopoda (Crustacea: Oniscidea) of the Socotra Archipelago. Fauna of Arabia 20: 211-325.

Tomikawa K, Kakui K, Yamasaki H (2010) A new species of Psammogammarus (Amphipoda: Melitidae) from Kuchinoerabu Island, Japan, with a note on its feeding habits. Zoological Science 27: 615-626. doi: 10.2108/zsj.27.615

Trontelj P, Douady CJ, Fišer C, Gibert J, Gorički Š, Lefébure T, Sket B, Zakšek V (2009) A molecular test for cryptic diversity in ground water: how large are the ranges of macrostygobionts? Freshwater Biology 54: 727-744. doi: 10.1111/j.1365-2427.2007.01877.x

Van der Ham JL, Vonk R (2003) A phylogenetic analysis of the Eriopisa complex (Crustacea: Amphipoda: Melitidae) and a new species from beach interstitial in Venezuela. Journal of Natural History 37: 779-796. doi: 10.1080/00222930110108344

Vonk R (1990) Psammogammarus stocki n.sp. (Crustacea, Amphipoda, Melitidae) from beach interstitia on Tenerife. Bijdragen tot de Dierkunde 60: 271-276.

Vonk R, Sánchez E (1991) A new marine interstitial ingolfiellid (Crustacea, Amphipoda, Ingolfiellidea) from Tenerife and Hierro. Hydrobiologia 223: 293-299. doi: 10.1007/BF00047646

Vonk R, Schram FR (2003) Ingolfiellidea (Crustacea, Malacostraca, Amphipoda): a phylogenetic and biogeographic analysis. Contributions to Zoology 72: 39-72. 
Vonk R, Stock JH (1987) Psammogammarus longidactilus n.sp., a new cave amphipod (Crustacea) and other stygobiont amphipods from Bonaire. Stygologia 3: 241-251.

Vonk R, Hoeksema BW, Jaume D (2011) A new marine interstitial Psammogammarus (Crustacea, Amphipoda, Melitidae) from Gura Ici Island, off western Halmahera (North Moluccas, Indonesia), and an overview of the genus. ZooKeys 128: 53-73. doi: 10.3897/ zookeys.128.1661

Wallace CC, Zahir H (2007) The "Xarifa" expedition and the atolls of the Maldives, 50 years on. Coral Reefs 26: 3-5. doi: 10.1007/s00338-006-0188-4 